\title{
Dear Mr Carter
}

ZACHARY RILEY

Dear Mr Carter,

I'm not supposed to be writing this letter . . . but then, she wasn't supposed to go out like that either.

I don't suppose you know me. Maybe you know of me, but I suspect you wouldn't know about me and I guess it takes an awful lot to ever really know someone now, doesn't it? So, it seems that it is somewhere between of and about where you and I must rest, but perhaps this letter may draw us closer together.

It's been nearly thirty years now since it all happened. I wonder how often it is that you wonder-how much thought do you afford to different circumstances, Mr Carter? How void or vivid is your imagined world, had her circumstances been different?

Perhaps it was so taxing then that now it's best to give little consideration to these things. If I'm right about that, I'm sorry to dredge up things that should be left untouched. But I do wonder, Mr Carter, and curiosity compels me to ask about these things. See, you knew what it was like back then. It was a lived experience for you. It was entirely palpable and rich in emotion. I, on the other hand, have very little to infer from; just titbits of information that my untamed curiosity seeks out. 
Now I don't know you, Mr Carter, but I do wonder, from time to time, about your life. I'm sorry for the platitude, but I hope that these days you're in a 'good place'-that you have since been able to nurture something indispensably wholesome in the wake of what was indisputably woeful. I wonder whether you were able to move on and discover something or someone that still lasts.

I like to imagine that you have a beautiful family now. I imagine you having daughters — at least two of them. I don't know why my imagination would do such a thing, but I can't help what it is that I imagine.

I think one daughter would have been difficult at first, but, had you had two, perhaps neither would have been at risk of feeling like a replacement.

I don't have any siblings, Mr Carter. My mother managed to find someone after you though, but it didn't last. They hadn't known each other even a year before I was born and there wasn't enough bedrock between them from which to build anything longstanding.

That's not to say my parents didn't try to keep things lasting - there's enough audible memories of outpoured emotion to know that they did try. Everything I remember of their trying is a whirlwind, and I think it all moved by too quickly for any one of us to realise what was at stake. And it's hard when you're young to not see yourself to blame for things that aren't really your fault.

Did you know that there's a term some people use for children such as myself, Mr Carter? I wonder if you've come across it yourself. I first read about it in a newspaper article that described children born out of loss as 'rainbow babies' - the 'beautiful gift' after the 'troubling storm'.

Perhaps we are beautiful and perhaps we are a cause for celebration, but the refracted, patterned light that is typical of a rainbow can only ever be revealed after a downpour-our arc is forever bound by this rule of nature, $\mathrm{Mr}$ Carter. So long as the 'rainbow baby' lives, we live by virtue of the rain - rain and ray, forever entwined, inseparably separate yet somehow unified in that coloured arc.

It feels as though, in many ways, she and I are a unity of opposites: dead and living, feminine and masculine, youth-bound and condemned 
to aging, the eternal spirit and the finite flesh. Like the faces of a coin, we never see our other side-our counterpart-and our two opposed faces will never touch.

You and I, Mr Carter, share a common bond and rotate on our own axes. Your daughter, my mother, and the tiny plaque on the children's lawn at that necropolis is all that we have in common. It is strange to think on these things and to know that a pivotal movement can change the trajectories of entire lives. Any moment can draw us closer, just as it can condemn us to be apart.

I hope you can forgive me for saying this Mr Carter, but I believe I would never be here had she not died-and I believe that if I am glad to be here then I must rejoice in her passing. I suppose I just wanted you to know this.

P.S.- - It occurs to me that I don't know your first name. Nor did I have an address to send this letter to. So, if this letter has reached you, then you should know that I still visit her too. 